Penelitian

\title{
Efektivitas Herbal Cair Kombinasi Daun Pepaya dan Kelopak Bunga Rosella Sebagai Antihipertensi
}

\section{Effectiveness of Herbal Liquid Combination of Papaya Leaves Extract and Rosella Flower Petals as Antihypertensive}

\author{
Erni Rustiani ${ }^{1^{*}}$, Moerfiah $^{2}$, Pungky Umi Sa'diyah ${ }^{3}$ \\ ${ }^{1,3}$ Program Studi Farmasi, Fakultas Matematika dan Ilmu Pengetahuan Alam, \\ Universitas Pakuan, Indonesia \\ ${ }^{2}$ Program Studi Biologi, Fakultas Matematika dan Ilmu Pengetahuan Alam, \\ Universitas Pakuan, Indonesia \\ *Penulis untuk korespondensi: e_rustiani@yahoo.com \\ Diterima 14 Juli 2019, Disetujui 10 Januari 2020
}

\begin{abstract}
ABSTRAK
Hipertensi terjadi apabila tekanan darah sistol lebih dari $129 \mathrm{mmHg}$ dan tekanan darah diastol lebih dari $90 \mathrm{mmHg}$. Penelitian ini bertujuan untuk mengetahui pengaruh pemberian herbal cair kombinasi tersebut terhadap penurunan tekanan darah pada tikus putih jantan Sprague-Dawley yang diinduksi larutan $\mathrm{NaCl} 5 \%$. Hewan uji yang digunakan terdiri dari 20 ekor tikus dengan bobot 200-300 gram dan dibagi menjadi 5 kelompok perlakuan. Kelompok perlakuan terdiri dari dosis I (0,27 mL/200 gBB), dosis II (0,54 mL/200 gBB), kontrol positif I (obat herbal merk X 6,48 mg/200 gBB), kontrol positif II (kaptopril 1,35 mg/200 gBB), dan kelompok kontrol negatif yang hanya diberikan akuades. Berdasarkan penelitian yang dilakukan dapat dinyatakan bahwa pemberian herbal cair dapat menurunkan tekanan darah pada tikus setelah 18 hari penggunaan. Dosis II (0,54 mL/200 gBB) merupakan dosis paling baik untuk menurunkan tekanan darah pada tikus putih jantan Sprague-Dawley dengan lama waktu pemberian paling baik untuk sistol pada hari ke-10 dan diastol hari ke-15.
\end{abstract}

Kata kunci: herbal cair, ekstrak daun pepaya, kelopak bunga rosella, antihipertensi

\begin{abstract}
Hypertension occurs when systolic blood pressure more than $129 \mathrm{mmHg}$ and diastolic blood pressure more than 90 $\mathrm{mmHg}$. This study aimed to determine the effect of the combination of herbal liquid to decrease high blood pressure in Sprague-Dawley white male rats induced by $5 \% \mathrm{NaCl}$ solution. Animals test were used consisted of 20 rats weighing 200$300 \mathrm{~g}$ and divided into 5 treatment groups. The treatment group consisted of the dose I ( $0.27 \mathrm{~mL} / 200 \mathrm{gBW})$, the dose II ( $0.54 \mathrm{~mL} / 200 \mathrm{gBW}$ ), positive control I (herbal medicine X Brand $6.48 \mathrm{mg} / 200 \mathrm{gBW}$ ), positive control II (captopril 1.35 $\mathrm{mg} / 200 \mathrm{gBW}$ ) and negative control group were only given aquadest. Based on study can be stated that the administration of the combination of herbal liquid can lower blood pressure in rats after 18 days treatment. Dose II $(0.54 \mathrm{~mL} / 200 \mathrm{~kg})$ is the best dose for lowering blood pressure in Sprague-Dawley white male rats with the best time for systole on day 10 and diastole on day 15.
\end{abstract}

Keywords: herbal liquid, papaya leaf extract, rosella flower petals, antihypertensive 


\section{PENDAHULUAN}

Penyakit hipertensi saat ini masih menjadi masalah di negara berkembang, seperti Indonesia. Menurut penelitian Rahajeng \& Tuminah (2009) tingkat kejadian hipertensi di Indonesia mencapai 32,2\%. Langkah yang dapat dilakukan untuk menekan tingkat kejadiaan hipertensi adalah dengan pengobatan tradisional menggunakan obat herbal. Bahan alam yang selama ini telah digunakan sebagai antihipertensi diantaranya adalah daun pepaya dan kelopak bunga rosella.

Penelitian mengenai efektivitas kelopak bunga rosella telah dilakukan oleh Hardiyanto (2014), penelitian ini menunjukkan bahwa $2 \mathrm{~g} / 70 \mathrm{KgBB}$ serbuk simplisia kelopak bunga rosella yang terdapat di dalam sediaan sirup kombinasi kelopak bunga rosella dan herba seledri dapat menurunkan hipertensi pada manusia. Selain itu secara empiris rebusan 5 lembar daun pepaya juga terbukti dapat menurunkan hipertensi (Khaerani 2014).

Berdasarkan analisis fitokimia kualitatif yang dilakukan oleh Pauline et al. (2013), daun Carica papaya L. mengandung alkaloid, flavonoid, saponin, tanin dan glikosida. Selain mengandung beberapa metabolit tersebut daun pepaya juga kaya akan kandungan mineral seperti $\mathrm{Ca}, \mathrm{Mg}, \mathrm{Na}, \mathrm{K}$, Fe dan $\mathrm{Mn}$ (Ayoola dan Adeyeye 2010). Di antara banyaknya metabolit yang terkandung dalam daun pepaya, metabolit yang diperkirakan memiliki pengaruh menurunkan tekanan darah adalah flavonoid serta kalium.

Senyawa kimia utama yang ditemukan dalam kelopak bunga rosella adalah asam organik, terutama asam sitrat dan asam malat serta antosianin. Antosianin yang ditemukan berlimpah dalam kelopak bunga Hibiscus sabdariffa $L$. dianggap sebagai fitokimia yang bertanggung jawab atas efek antihipertensi (Hopkins et al. 2013).

Berdasarkan kesamaan khasiat ini, maka telah dilakukan formulasi sediaan herbal cair kombinasi dari kedua bahan tersebut oleh Rahmawati (2015) dengan menggunakan beberapa jenis pemanis. Berdasarkan uji hedonik dan uji stabilita yang dilakukan pada penelitian tersebut, didapatkan formula terbaik yang terdiri dari 0,23\% ekstrak kental daun pepaya, $14 \%$ serbuk simplisia kelopak bunga rosella, $1,5 \%$ natrium benzoat dan $16 \%$ pemanis madu yang terkandung dalam $250 \mathrm{~mL}$ herbal cair.

Khasiat dari herbal cair kombinasi ekstrak daun pepaya dan kelopak bunga rosella yang telah dibuat ini belum teruji, oleh sebab itu perlu dilakukan penelitian untuk menguji efektivitasnya sebagai antihipertensi. Tujuan dari penelitian ini adalah untuk melakukan pengujian efek antihipertensi serta mengetahui dosis dan lama waktu pengobatan yang paling baik dari herbal cair kombinasi ekstrak daun pepaya dan kelopak bunga rosella pada tikus putih jantan galur Sprague-Dawley yang diinduksi dengan larutan $\mathrm{NaCl} 5 \%$.

\section{BAHAN DAN METODE}

Bahan yang digunakan adalah daun pepaya (3-5 daun dari atas pucuk) serta kelopak bunga rosella, pemanis madu, natrium benzoat, tikus putih jantan galur Sprague-Dawley dengan bobot 200-300 g sebanyak 20 ekor, larutan $\mathrm{NaCl} 5 \%$, obat herbal merk $\mathrm{X}$, kaptopril dan pakan standar. Alat yang digunakan adalah vaccum dryer (Ogawa ${ }^{\circledR}$ ), homogenizer (IKA $\left.{ }^{\circledR}\right)$, alat pengukur tekanan darah Non-Invasived Rat Tail Blood Pressure (CODA $\left.{ }^{\circledR}\right)$, kandang hewan coba beserta kelengkapan pemberian pakan dan alat-alat gelas.

\section{Pembuatan Ekstrak Kental Daun Pepaya}

Berdasarkan penelitian yang dilakukan Rahmawati (2015) ekstrak kental daun pepaya dibuat dengan metode infudasi. Sebanyak $300 \mathrm{~g}$ serbuk simplisia daun pepaya yang telah diayak dengan ayakan mesh 40 dicampurkan dengan 1,5 L air. Campuran tersebut kemudian direbus selama 15 menit, dihitung saat suhu telah mencapai $90^{\circ} \mathrm{C}$ sambil diaduk sesekali. Serkai selagi panas melalui kain batis, kemudian ditambahkan air panas melalui ampas hingga diperoleh volume infus yang dikehendaki, yaitu 1,5 L (DepKes RI, 2000). Ekstrak cair yang diperoleh dari tahap ini selanjutnya dikentalkan dengan vaccum dryer (Rahmawati 2015).

\section{Pembuatan Ekstrak Cair Kelopak Bunga Rosella}

Ekstrak cair kelopak bunga rosella dibuat dengan merebus $35 \mathrm{~g}$ simplisia kelopak bunga rosella yang telah diayak dengan mesh 40. Simplisia dibungkus dengan menggunakan kain batis, kemudian direbus dalam $100 \mathrm{~mL}$ air dengan suhu $70-80^{\circ} \mathrm{C}$ selama 30 menit (Rahmawati 2015).

\section{Pembuatan Sediaan Herbal Cair}

Sediaan herbal cair kombinasi ekstrak daun pepaya dan kelopak bunga rosella dibuat berdasarkan formula terbaik yang diperoleh pada penelitian Rahmawati (2015). Berdasarkan uji hedonik dan uji stabilita yang dilakukan pada penelitian tersebut, diperoleh formula terbaik yang terdiri dari 0,23\% ekstrak kental daun pepaya, $14 \%$ serbuk simplisia 
kelopak bunga rosella, 1,5\% natrium benzoate, dan $16 \%$ pemanis madu dalam $250 \mathrm{~mL}$ sediaan herbal cair.

\section{Pemeliharaan Hewan Coba}

Hewan coba yang digunakan dalam penelitian ini adalah tikus putih jantan galur Sprague-Dawley dengan bobot badan sekitar 200-300 g. Sebanyak 20 ekor tikus dengan klasifikasi tersebut dibagi menjadi 5 kelompok perlakuan dengan masing-masing kelompok terdiri dari 4 ekor tikus. Semua hewan coba diaklimatisasi selama 7 hari di Laboratorium Farmasi Fakultas Matematika dan IImu Pengetahuan Alam Universitas Pakuan, Bogor dan diberi pakan standar serta minum secara ad libitum.

\section{Induksi dengan Larutan $\mathrm{NaCl}$ 5\%}

Setelah diaklimatisasi, selanjutnya tikus diinduksi supaya mengalami hipertensi sampai tekanan darahnya melebihi tekanan darah normal pada tikus atau $\geq 129 / 91 \mathrm{mmHg}$. Induksi dilakukan dengan menggunakan larutan $\mathrm{NaCl} 5 \%$ sebanyak $1 \mathrm{~mL}$ yang diberikan secara oral selama 10 hari. Sebelum dan setelah induksi, tikus diukur tekanan darahnya dengan Tail Cuff Method menggunakan alat NonInvasived Rat Tail Blood Pressure (CODA ${ }^{\circledR}$ ).

\section{Pengobatan dengan Herbal Cair Kombinasi Ekstrak Daun Pepaya dan Kelopak Bunga Rosella}

Dosis yang digunakan pada penelitian ini diambil dari dosis yang telah ditentukan pada penelitian sebelumnya. Dosis dibuar bertingkat untuk mendapatkan dosis yang paling baik yaitu menjadi 2 dosis. Dosis I merupakan dosis yang telah ditentukan oleh Rahmawati (2015) dan dosis II merupakan $2 \mathrm{x}$ dosis I. Pada penelitian ini digunakan dua kontrol positif yang bertujuan untuk membandingkan efek antihipertensi herbal cair kombinasi ekstrak daun pepaya dan kelopak bunga rosella dengan sediaan herbal (obat herbal merk $\mathrm{X}$ ) dan obat sintetik (kaptopril) yang beredar di masyarakat. Adapun dosis yang diberikan pada masingmasing perlakuan adalah sebagai berikut:
a. Kontrol positif I : obat herbal merk $X$ dengan dosis $6,48 \mathrm{mg} / 200 \mathrm{gBB}$.
b. Kontrol positif II : kaptopril dengan dosis 1,35 $\mathrm{mg} / 200 \mathrm{gBB}$.
C. Dosis I
: herbal cair dengan dosis 0,27
d. Dosis II $\mathrm{mL} / 200 \mathrm{gBB}$.
e. Kontrol negatif : diberikan air.

Seluruh tikus perlakuan diberikan obat secara oral dengan volume pemberian sebanyak $1 \mathrm{~mL}$ selama 18 hari.

\section{Pengukuran Tekanan Darah}

Pengukuran tekanan darah pada tikus dilakukan dengan Metode Tail Cuff menggunakan alat NonInvasived Rat Tail Blood Pressure (CODA $\left.{ }^{\circledR}\right)$. Metode ini merupakan metode tidak langsung dan merupakan suatu prosedur non-invasive (Kurtz et al. 2005). Metode ini terdiri dari manset karet eksternal yang ditempatkan pada ekor tikus yang ditujukan untuk menyumbat aliran darah. Penyempitan pada manset digunakan untuk menyumbat arteri yang terdapat pada ekor (Pauline 2011). Non-Invasived Rat Tail Blood Pressure (CODA ${ }^{\circledR}$ ) menggunakan sensor berupa Volume Pressure Recording (VPR), sensor ini memanfatkan metode volumetrik untuk mengukur volume darah total di bagian ekor (Daugherty et al. 2009).

\section{Rancangan Penelitian (Analisis Data)}

Terdapat dua faktor yang diamati yaitu dosis (faktor A) dan lama waktu pengobatan (faktor B). Bahan dan lingkungan pada penelitian ini keduanya homogen, maka rancangan penelitian yang digunakan adalah analisis sidik ragam untuk RAL Faktorial dengan kombinasi perlakuan $5 \times 5$. Setelah didapatkan kesimpulan dari analisis sidik ragam selanjutnya data dianalisis kembali dengan menggunakan Uji Lanjut Duncan. Uji Lanjut Duncan ini dilakukan untuk mengetahui perbedaan antar perlakuan.

\section{HASIL}

\section{Ekstrak Kental Daun Pepaya dan Ekstrak Cair Kelopak Bunga Rosella}

Rata-rata kadar air serbuk simplisia daun pepaya dan kelopak bunga rosella berturut-turut adalah $3,34 \%$ dan 2,73\%. Ekstrak kental daun pepaya diperoleh melalui metode infundasi dengan memanaskan 300,4 g serbuk simplisia dalam 1,5 L air. Pada proses infundasi ini diperoleh ektrak cair 


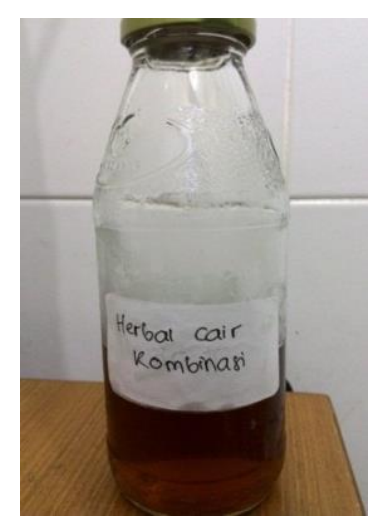

Gambar 1 Herbal cair kombinasi ekstrak daun pepaya dan kelopak bunga rosella

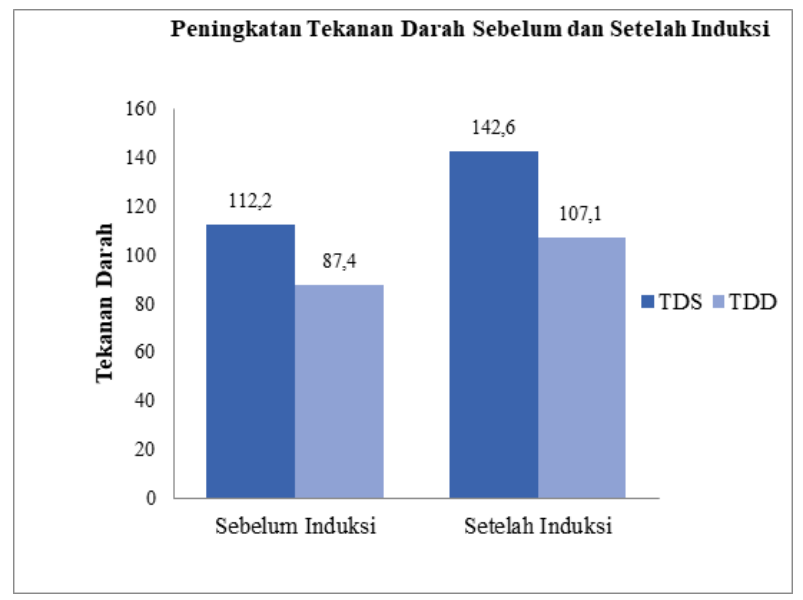

Gambar 2 Rata-rata pengukuran TDS dan TDD tikus sebelum dan setelah induksi dengan larutan $\mathrm{NaCl} 5 \%$

yang kemudian dipekatkan dengan menggunakan vaccum dryer. Ekstrak kental yang diperoleh adalah $66,48 \mathrm{~g}$ dengan rendemen ekstrak sebesar $22,13 \%$.

\section{Herbal Cair Kombinasi Ekstrak Daun Pepaya dan Kelopak Bunga Rosella}

Herbal cair kombinasi yang dibuat memiliki rasa manis dengan aroma yang khas dan berwarna cokelat kemerahan. Herbal cair kombinasi dapat dilihat pada Gambar 1.

\section{Hasil Induksi dengan Larutan $\mathrm{NaCl}$ 5\%}

Hasil penelitian menunjukkan bahwa pemberian larutan $\mathrm{NaCl} 5 \%$ secara oral selama 10 hari dapat meningkatkan tekanan darah tikus. Data hasil pengukuran tekanan darah sistol (TDS) dan diastol (TDD) tikus sebelum dan setelah induksi dapat dilihat pada Gambar 2.
Berdasarkan Gambar 1 terlihat rata-rata TDS sebelum induksi sebesar $112,2 \mathrm{mmHg}$, sedangkan rata-rata TDD sebesar $87,4 \mathrm{mmHg}$. Rata-rata tekanan darah sebelum induksi pada semua perlakuan telah memenuhi syarat tekanan darah normal pada tikus, yaitu $\leq 129 / 91 \mathrm{mmHg}$ (Kent Scientific 2016). Setelah 10 hari induksi, TDS dan TDD pada tikus mengalami peningkatan menjadi $142,6 \mathrm{mmHg}$ dan $107,1 \mathrm{mmHg}$ dengan persen peningkatan masing-masing sebesar $27,1 \%$ dan $22,9 \%$. Nilai rata-rata tekanan darah setelah induksi telah melebihi tekanan darah normal pada tikus, sehingga dapat dikatakan bahwa tikus telah mengalami hipertensi.

Hasil Perlakuan Herbal Cair Kombinasi Ekstrak Daun Pepaya dan Kelopak Bunga Rosella terhadap Penurunan Tekanan Darah Tikus

Pengobatan dilakukan secara oral selama 18 hari dan tekanan darahnya diukur pada hari ke-0, 5, 10, 15 dan 18. Selama tahap pengobatan tikus tetap di- 
induksi dengan larutan $\mathrm{NaCl}$ 5\% untuk memastikan bahwa penurunan tekanan darah bukan disebabkan karena kondisi fisiolgis tikus yang masih normal, namun karena perlakuan yang diberikan. Pada hari ke-5, perlakuan kontrol positif I dan II penurunan tekanan darahnya telah mencapai tekanan darah normal. Sedangkan perlakuan dosis I dan II membutuhkan waktu lebih dari 5 hari untuk mencapai tekanan darah normal. Tekanan darah normal pada tikus terjadi apabila TDS $\leq 129 \mathrm{mmHg}$ (Kent Scientific 2016). Nilai rata-rata dan standar deviasi TDS dapat dilihat pada Tabel 1 .

Huruf superskrip yang diperoleh dari Uji Lanjut Duncan menunjukkan bahwa kontrol positif I dan II tidak berbeda nyata. Kedua kontrol positif berbeda nyata dengan dosis II dan berbeda sangat nyata dengan dosis I. Untuk lama waktu pemberian terhadap penurunan TDS menunjukkan pengaruh yang berbeda nyata pada semua hari, kecuali pada hari ke-18.

Kontrol positif I dan II mengalami penurunan TDD normal pada hari ke-10, sedangkan dosis I dan II terjadi pada hari ke-15. Tekanan darah normal pada untuk TDD $\leq 91 \mathrm{mmHg}$ (Kent Scientific 2016). Nilai rata-rata dan standar deviasi TDD dapat dilihat pada Tabel 2.

Huruf superskrip yang diperoleh dari Uji Lanjut Duncan menunjukkan bahwa kontrol positif I dan II memiliki pengaruh yang tidak berbeda nyata dengan dosis II, sedangan dengan dosis I memiliki pengaruh yang bebeda nyata. Apabila dibandingkan dengan kontrol negatif, dosis I dan dosis II masing-masing berbeda nyata dan berbeda sangat nyata. Untuk pengaruh lama waktu pemberian terhadap TDD juga menunjukkan pengaruh yang berbeda nyata pada semua hari, kecuali pada hari ke-18 yang menunjukkan pengaruh yang tidak berbeda nyata. Grafik penurunan TDS dan TDD pada tikus dapat dilihat pada Gambar 3. sedangkan persentae penurunan TDS dan TDD pada tikus dapat dilihat pada Tabel 3. Pada Tabel 3 menunjukkan TDS dan TDD pada semua perlakuan mengalami penurunan. Di antara dosis I dan dosis II persentase penurunan yang paling tinggi adalah dosis II dengan persentase penurunan TDS $23,47 \%$ dan TDD $23,33 \%$.

\section{PEMBAHASAN}

\section{Ekstrak Kental Daun Pepaya dan Ekstrak Cair} Kelopak Bunga Rosella

Hasil menunjukkan bahwa kedua serbuk simplisia memenuhi syarat DepKes RI (1985), yaitu tidak lebih dari $5 \%$. Hasil rendemen yang diperoleh mendekati hasil rendemen dari penelitian sebelumnya, yaitu $21 \%$ (Rahmawati 2015).

Tabel 1 Rata-rata TDS setelah pengobatan

\begin{tabular}{|c|c|c|c|c|c|c|}
\hline \multirow{2}{*}{ Kelompok } & \multicolumn{6}{|c|}{ Penurunan TDS Hari Ke- } \\
\hline & 0 & 5 & 10 & 15 & 18 & $\bar{x}$ \\
\hline $\mathrm{K}+\mathrm{I}$ & $141,0^{\mathrm{ab}} \pm 4,7$ & $129,3^{\text {ef }} \pm 4,8$ & $110,8^{\mathrm{ijk}} \pm 5,7$ & $106,8^{\mathrm{jkl}} \pm 5,1$ & $105,0^{\mathrm{kl}} \pm 2,8$ & $118,6^{c}$ \\
\hline $\mathrm{K}+\mathrm{II}$ & $144,3^{a} \pm 5,6$ & $126,0^{\mathrm{fg}} \pm 3,9$ & $108,0^{\mathrm{ijk}} \pm 1,6$ & $105,3^{\mathrm{kl}} \pm 2,2$ & $104,5^{1} \pm 2,5$ & $117,6^{d}$ \\
\hline DI & $145,0^{a} \pm 1,4$ & $140,0^{a b} \pm 3,6$ & $130,3^{\text {def }} \pm 1,3$ & $119,5^{h} \pm 3,3$ & $113,5^{i} \pm 3,1$ & $129,7^{b}$ \\
\hline DII & $142,8^{\mathrm{a}} \pm 4,2$ & $135,3^{\mathrm{bcd}} \pm 4,8$ & $121,8^{\mathrm{gh}} \pm 3,0$ & $111,5^{i j} \pm 1,0$ & $109,3^{i j k} l \pm 2,8$ & $124,1^{\mathrm{c}}$ \\
\hline K- & $141,3^{a b} \pm 3,3$ & $139,0^{\mathrm{ab}} \pm 3,6$ & $136,5^{b c} \pm 4,1$ & $132,5^{\mathrm{cde}} \pm 4,2$ & $131,8^{\text {cdef }} \pm 5,9$ & $136,2^{\mathrm{a}}$ \\
\hline $\bar{x}$ & $142,9^{\mathrm{a}}$ & $133,9^{b}$ & $121,5^{c}$ & $115,1^{\mathrm{d}}$ & $112,8^{\mathrm{d}}$ & \\
\hline
\end{tabular}

Tabel 2 Rata-rata TDD setelah pengobatan

\begin{tabular}{|c|c|c|c|c|c|c|}
\hline \multirow{2}{*}{ Kelompok } & \multicolumn{6}{|c|}{ Penurunan TDD Hari Ke- } \\
\hline & 0 & 5 & 10 & 15 & 18 & $\bar{x}$ \\
\hline $\mathrm{K}+\mathrm{I}$ & $109,0^{a} \pm 12,3$ & $93,5^{\text {cdefgh }} \pm 2,4$ & $91,3^{\text {efghij }} \pm 10$ & $77,3^{\mathrm{kl}} \pm 7,8$ & $77,3^{\mathrm{kl}} \pm 5,7$ & $89,7^{c}$ \\
\hline $\mathrm{K}+\mathrm{II}$ & $110,3^{a} \pm 2,1$ & $98,8^{\text {abcdef }} \pm 5,9$ & $81,8^{\mathrm{ijkl}} \pm 1,7$ & $76,3^{\mathrm{kl}} \pm 3,5$ & $70,3^{\prime} \pm 1,5$ & $87,5^{c}$ \\
\hline DI & $106,5^{a b} \pm 9,9$ & $102,5^{\text {abcde }} \pm 1,9$ & $95,8^{\text {bcdefg }} \pm 5,4$ & $87,3^{\text {fghijk }} \pm 6,9$ & $84,8^{\text {ghijk }} \pm 9,0$ & $94,3^{b}$ \\
\hline DII & $105,0^{\mathrm{abc}} \pm 10,1$ & $99,8^{\mathrm{abcde}} \pm 5,4$ & $92,5^{\text {defghi }} \pm 3,7$ & $83,3^{\text {hijk }} \pm 16,7$ & $80,5^{\mathrm{jkl}} \pm 2,5$ & $92,2^{b c}$ \\
\hline K- & $104,8^{\mathrm{abc}} \pm 7,8$ & $103,8^{\text {abcd }} \pm 6,8$ & $102,5^{\text {abcde }} \pm 7,7$ & $96,3^{\text {bcdefg }_{ \pm 1,0}}$ & $94,0^{\text {cdefgh }} \pm 6,2$ & $100,3^{a}$ \\
\hline $\bar{x}$ & $107,1^{\mathrm{a}}$ & $99,7^{\mathrm{b}}$ & $92,8^{c}$ & $84,1^{d}$ & $80,3^{d}$ & \\
\hline
\end{tabular}




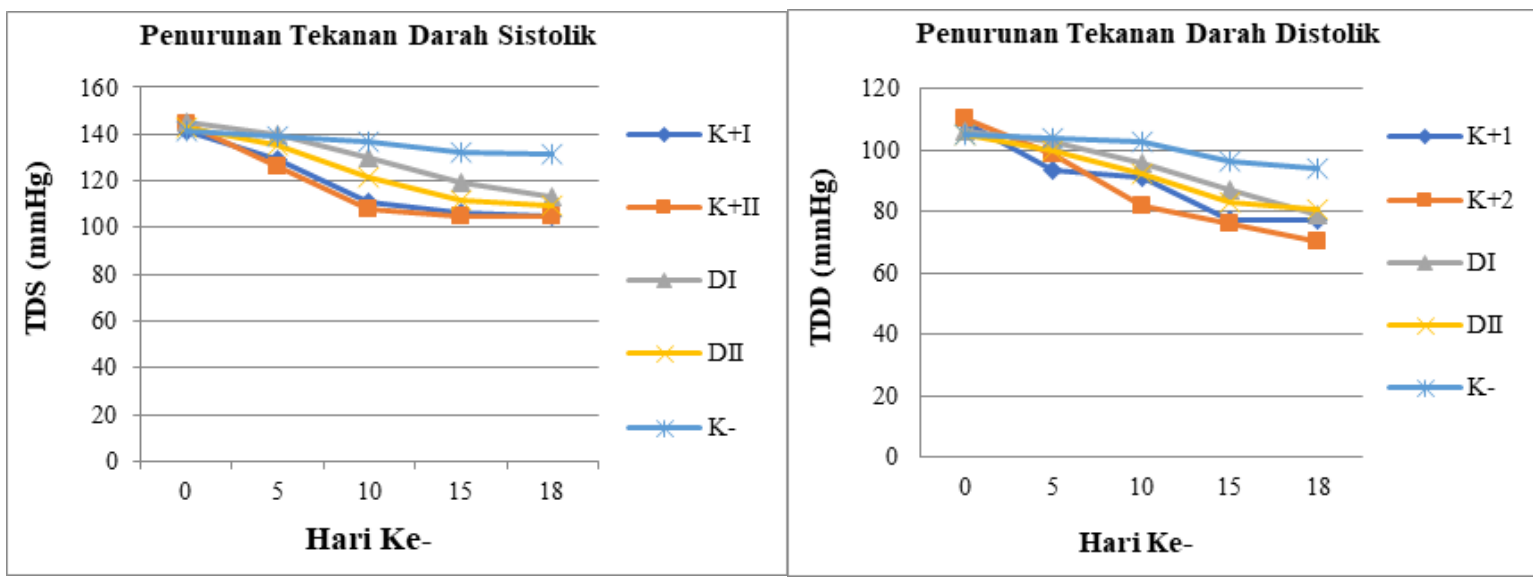

Gambar 3 Grafik rata-rata penurunan TDS dan TDD selama pengobatan

Tabel 3 Persentase rata-rata penurunan tekanan darah setelah pengobatan

\begin{tabular}{|c|c|c|c|c|c|c|c|c|c|c|}
\hline \multirow{2}{*}{ Kelompok } & \multicolumn{5}{|c|}{ Persentase Rata-rata TDS (\%)/Hari } & \multicolumn{5}{|c|}{ Persentase Rata-rata TDD (\%)/Hari } \\
\hline & 5 & 10 & 15 & 18 & $\bar{x}$ & 5 & 10 & 15 & 18 & $\bar{x}$ \\
\hline $\mathrm{K}+\mathrm{l}$ & $-7,35$ & $-20,61$ & $-23,48$ & $-24,73$ & $-19,04$ & $-14,22$ & $-16,28$ & $-29,13$ & $-29,13$ & $-22,19$ \\
\hline $\mathrm{K}+\mathrm{II}$ & $-12,65$ & $-25,13$ & $-27,04$ & $-27,56$ & $-23,10$ & $-10,43$ & $-25,85$ & $-30,84$ & $-36,28$ & $-25,85$ \\
\hline $\mathrm{DI}$ & $-3,45$ & $-10,17$ & $-17,59$ & $-21,72$ & $-13,23$ & $-3,76$ & $-10,09$ & $-18,08$ & $-20,42$ & $-13,09$ \\
\hline DII & $-5,25$ & $-14,71$ & $-21,89$ & $-23,47$ & $-16,33$ & $-5,00$ & $-11,90$ & $-20,71$ & $-23,33$ & $-15,24$ \\
\hline K- & $-1,59$ & $-3,36$ & $-6,19$ & $-6,73$ & $-4,47$ & $-1,43$ & $-2,61$ & $-8,55$ & $-10,69$ & $-5,82$ \\
\hline
\end{tabular}

Keterangan: - berarti terjadi penurunan

Herbal Cair Kombinasi Ekstrak Daun Pepaya dan Kelopak Bunga Rosella

Hasil ini sesuai dengan uji organoleptik yang dilakukan oleh Rahmawati (2015), yang menyatakan bahwa herbal cair dengan pemanis madu memiliki aroma khas dan berwarna cokelat kemerahan.

\section{Hasil Induksi dengan Larutan $\mathrm{NaCl} 5 \%$}

Kenaikan tekanan darah pada tikus ini disebabkan karena konsumsi berlebih natrium $\left[\mathrm{Na}^{+}\right]$yang terdapat dalam $\mathrm{NaCl}$. Asupan $\mathrm{NaCl}$ yang tinggi dapat menyebabkan peningkatan $\left[\mathrm{Na}^{+}\right]$di plasma dan di cairan serebrospinal (Huang et al. 2004). Peningkatan $\left[\mathrm{Na}^{+}\right]$di plasma menginduksi sekresi Endogenous Ouabain (EO) dengan mekanisme yang belum diketahui dengan jelas. Peningkatan $\left[\mathrm{Na}^{+}\right]$di cairan serebrospinal menyebabkan peningkatan aktivitas saraf simpatik yang merupakan pemicu terjadinya vasokontriksi. Peningkatan $\left[\mathrm{Na}^{+}\right]$di cairan serebrospinal ini juga memicu terjadinya sekresi EO secara lokal (Blaustein et al. 2012).

Implikasi dari peningkatan sekresi EO pada cairan serebrospinal dan plasma adalah pengaktifan sistem renin-angiotensin di otak yang pada akhirnya akan mengakibatkan peningkatan tekanan darah (Blaustein et al. 2012).
Sistem renin-angiotensin terlibat dalam proses pengaturan tekanan darah, renin bekerja pada substrat angiotensinogen untuk menghasilkan angiotensin I, kemudian dengan adanya Angiotensinconverting Enzyme (ACE) diubah kembali menjadi angiotensin II (Harmita et al. 2011). Angiotensin II menyebabkan vasokontriksi dan perangsangan aldosteron yang menyebabkan retensi air dan natrium di ginjal sehingga meningkatkan volume darah dan pada akhirnya meningkatkan cardiac output (CO). Peningkatan $\mathrm{CO}$ ini merupakan salah satu faktor utama terjadinya hipertensi (Departemen Farmakologi dan Terapeutik FKUI 2011).

\section{Hasil Perlakuan Herbal Cair Kombinasi Ekstrak} Daun Pepaya dan Kelopak Bunga Rosella terhadap Penurunan Tekanan Darah Tikus

Secara keseluruhan tekanan darah tikus jantan galur Sprague-Dawley setelah pengobatan dengan herbal cair mengalami penurunan TDD dan TDS. Herbal cair dosis I dan dosis II memiliki potensi sebagai penurun TDS, namun efektivitas yang ditimbulkan belum sebanding dengan kontrol positif Herbal cair dosis I dan II memiliki potensi sebagai penurun TDD, namun hanya dosis II yang memiliki efektivitas yang sebanding dengan kontrol positif. 
Hasil ini menunjukkan bahwa dosis II memiliki efek yang lebih baik dalam menurunkan tekanan darah pada tikus.

Kontrol positif I dan kontrol positif II yang digunakan pada penelitian ini merupakan obat penurun hipertensi yang sudah beredar luas di pasaran, sehingga efektivitas kedua obat ini dalam menurunkan hipertensi sudah teruji dengan baik. Selain itu, kontrol positif II (kaptopril) merupakan golongan obat sintetik yang efektivitasnya dapat dipastikan berada di atas obat-obat herbal, sebab obat sintetik terdiri dari senyawa aktif dengan konsentrasi yang tinggi dan sudah dimurnikan (Supriyatna et al. 2014).

Aktivitas penurunan tekanan darah disebabkan karena adanya kandungan flavonoid dan kalium pada daun pepaya serta adanya kandungan antosianin pada kelopak bunga rosella (Ayoola dan Adeyeye, 2010; Hopkins et al. 2013; Pauline et al. 2013). Flavonoid yang terdapat pada daun pepaya dapat menurunkan tekanan darah dengan meningkatkan fungsi endotel. Flavonoid memiliki aktivitas antioksidan yang dapat meningkatkan sintesis Nictric Oxide (NO) pada endotel. NO yang disintesis ini menyebabkan terjadinya vasodilatasi pada otot polos pembuluh darah dan dapat menurunkan tekanan darah (Machha dan Mustafa 2005). Kandungan kalium dalam daun pepaya memiliki mekanisme penurunan tekanan darah yang sama dengan obat diuretik tiazid. Peningkatan asupan kalium menyebabkan tubuh mengeluarkan lebih banyak natrium ke dalam urine (Kowalski 2010).

Kelopak bunga rosella mengandung antosianin yang terbukti dapat menurunkan tekanan darah dengan bertindak sebagai ACE Inhibitor. Berdasarkan analisis kinetik yang dilakukan menunjukkan bahwa kedua jenis antosianin ini dapat menghambat aktivitas ACE dengan mekanisme persaingan secara kompetitif untuk berikatan dengan sisi aktif enzim (Ojeda et al. 2010). Penghambatan aktivitas ACE ini mencegah tubuh membuat angiotensin II yang merupakan hormon yang dapat menyebabkan vasokontriksi dan retensi $\left[\mathrm{Na}^{+}\right]$dan air (DepKes RI 2006).

Mekanisme obat herbal merk X (kontrol positif I) memiliki kesamaan dengan mekanisme calcium channel blocker, sedikit 8-blocker serta diuretik (Supari 2002). Kaptopril (kontrol positif II) memiliki mekanisme sebagai ACE inhibitor (U.S. Department of Health and Human Services 2004).
Berdasarkan hasil penelitian ini dapat disimpulkan bahwa herbal cair kombinasi ekstrak daun pepaya dan kelopak bunga rosella terbukti dapat menurunkan tekanan darah pada tikus putih jantan galur Sprague-Dawley yang diinduksi larutan $\mathrm{NaCl} 5 \%$. Dosis herbal cair kombinasi ekstrak daun pepaya dan kelopak bunga rosella yang paling baik sebagai penurunan tekanan darah adalah dosis II $(0,54$ $\mathrm{mL} / 200 \mathrm{gBB}$ ) dengan waktu pengobatan yang paling baik untuk TDS pada hari ke-10 dan untuk TDD pada hari ke-15.

\section{UCAPAN TERIMA KASIH}

Terima kasih kepada Direktur Riset dan Pengabdian Masyarakat Ditjen Penguatan Riset dan Pengembangan Kementerian Riset, Teknologi dan Pendidikan Tinggi yang telah mendanai penelitian ini melalui Program Kreativitas Mahasiswa Tahun Anggaran 2016.

"Penulis menyatakan tidak ada konflik kepentingan dengan pihak-pihak yang terkait dalam penelitian ini".

\section{DAFTAR PUSTAKA}

Ayoola PB, Adeyeye A. 2010. Phytochemical and nutrient evaluation of Carica papaya (pawpaw) leaves. IJRRAS. 5(3): 325-328.

Blaustein MP, Leenen FH, Chen L, Golovina VA, Hamlyn JM, Pallone, TL, Van Huysse JW, Zhang J, Wier WG. 2012. How nacl raises blood pressure: a new paradigm for the pathogenesis of salt-dependent hypertension. Am J Physiol Heart Circ Physiol. 302: 1031-1049.

Daugherty A, Rateri D, Lu Hong, Balakrishnan A. 2009. Measuring blood pressure in mice using volume pressure recording, a tail-cuff method. Journal of Visualized Experiments. 27: 1-2.

Departemen Farmakologi dan Terapeutik FKUI. 2011. Farmakologi dan Terapi. Jakarta (ID): Badan Penerbit FKUI.

DepKes RI. 1985. Cara Pembuatan Simplisia. Jakarta (ID): Direktorat Jendral Pengawasan Obat dan Makanan. 
DepKes RI. 2000. Parameter Standar Umum Ekstrak Tumbuhan Obat. Jakarta (ID): Direktorat Pengawasan Obat Tradisional.

DepKes RI. 2006. Pharmaceutical Care Untuk Penyakit Hipertensi. Jakarta (ID): Direktorat Bina Farmasi Komunitas dan Klinik Ditjen Bina Kefarmasian dan Alat Kesehatan Departemen Kesehatan.

Hardiyanto DN. 2014. Uji efektivitas sediaan sirup kombinasi kelopak bunga rosella (Hibiscus Sabdariffa Linn.) dan herba seledri (Apium graveolens Linn.) sebagai antihipertensi terhadap tikus putih jantan (Sprague-Dawley). Skripsi. Universitas Pakuan. Bogor.

Harmita H, Harahap Y. 2011. Buku Ajar Kimia Medisinal. Jakarta (ID): Buku Kedokteran EGC.

Hopkins AL, Lamm MG, Funk J, Ritenbaugh C. 2013. Hibiscus sabdariffa $L$. In the treatment of hypertension and hyperlipidemia: a comprehensive review of animal and human studies. J. Fitote. 85: 84-94.

Huang BS, Van Vliet BN, Leenen FHH. 2004. Increases in csf $\left[\mathrm{Na}^{+}\right]$precede the increases in blood pressure in Dahl $\mathrm{s}$ Rats and SHR on a high-salt diet. Am J Physiol Heart Circ Physio. 287: 1160-1166.

Kent Scientific. 2016. What is the Normal Range for Blood Pressure in Mice and Rats?. https://www.kentscientific.com/Products/Specs/ SpecPopUp.asp? Mode=FAQ\&Specld=181. Diakses tanggal 14 Februari 2016.

Khaerani U. 2014. Bunga Sakti Basmi Berbagai Penyakit. Jakarta (ID): Dunia Sehat.

Kowalski RE. 2010. Terapi Hipertensi. Alih Bahasa: R. Ekawati. Bandung (ID): Qanita.

Kurtz TW, Griffin KA, Bidani AK, Davisson RL, Hall JE. 2005. Recommendations for blood pressure measurement in humans and experimental animals, part 2: blood pressure measurement in experimental animals. Arterioscler Thromb Vasc Biol. 25 (3): 22-33.
Machha A, Mustafa MR. 2005. Chronic treatment with flavonoids prevents endothelial dysfunction in spontaneously hypertensive rat aorta. J Cardiovasc Pharmacol. 46 (1): 36-40.

Ojeda D, Jiménez-Ferrer, Zamilpa E, HerreraArellano A, Tortoriello J, Alvarez L. 2010. Inhibition of Angiotensin Convertin Enzyme (ACE) activity by the anthocyanins delphinidin and cyanidin3-o-sambubiosides from Hibiscus sabdariffa. Journal of Ethnopharmacology. 127 (1): 7-10.

Pauline IA, Ogbonna AO, Eze FU. 2013. Phytochemical analysis of paw-paw (Carica papaya) leaves. Int. J. LifeSc. Bt \& Pharm. 2 (3): 347-351.

Pauline M, Avadhany ST, Maruthy KN. 2011. Noninvasive measurement of systolic blood pressure in rats: a simple technique. Al Ameen J Med Sci. 4 (4): 365-369.

Rahajeng E, Tuminah S. 2009. Prevalensi hipertensi dan determinannya di Indonesia. Majalah Kedokteran Indonesia. 59 (12): 570-587.

Rahmawati IN. 2015. Pengembangan Herbal Cair Kombinasi Ekstrak Daun Pepaya (Carica Papaya L.) dan Kelopak Bunga Rosella (Hibiscus Sabdariffa L.). Skripsi. Universitas Pakuan. Bogor.

Supari F. 2002. Lowering blood pressure effect of Apium graviolens (seledri) and Orthosipleon stamineus benth (kumis kucing) in mild and moderate hypertension. Med J Indones. 11 (4): 195-201.

Supriyatna, Moelyono MW, Iskandar, Febriyanti. 2014. Prinsip Obat Herbal: Sebuah Pengantar untuk Fitoterapi. Yogyakarta (ID): Deepublish.

U.S. Department of Health and Human Services. 2004. The Seventh Report of the Joint National Committee on Prevention, Detection, Evaluation, and Treatment of High Blood Pressure. Washington DC: U. S. Department of Health and Human Services. 